\title{
Mortality Influenced Factors for Outcome of Epidural Hematoma Patient Which Performed Emergency Craniotomy in M Djamil Hospital Padang Periode January-December 2017
}

\author{
Amrizal $^{1}$,Syaiful Saanin ${ }^{2}$
}

\begin{abstract}
Epidural Hematoma $(E D H)$ is the most common emergency case in neurosurgery, mortality rate was higher than other country. To determine the factors that influence outcome of EDH patients with performed emergency craniotomy. This descriptive analytic was conducted at Dr. M. Djamil General Hospital, Padang, Indonesia, we review the medical record all of EDH patient in 2017. Some parameters were analyzed in our study, ages $(p=0.012)$, gender $(p=0.418)$, inisial GCS $(p=0.146)$, pupil abnormality $(p=0.973)$, onset $(p=0.883)$ and time delayedfor surgery $(p=$ 0.146 ), the mortality rate was $7 / 26$ patients. Age has a significant difference on the outcome of EDH patients who underwent emergency craniotomy. Whereas gender, initial GCS, pupil abnormality, onset trauma, delayed time are determinat factors that influence outcome but not significant.
\end{abstract}

Keywords: epidural hematoma, mortality

\begin{abstract}
Abstrak
Epidural Hematoma (EDH) merupakan kegawatdaruratan di bagian bedah saraf, angka kematian masih tinggi dibandingkan Negara lain. Mengetahui faktor-faktor yang mempengaruhi mortalitas pasien EDH yang menjalanii kraniotomi emergensi. Penelitian Deskriptif Analitik ini dilakukan di RSUP Dr. M. Djamil, Padang, Indonesia, dengan melihat status rekam medis pasien EDH yang menjalani operasi kraniotomi selama tahun 2017. Beberapa parameter dalam analisis ini menilai hubungannya terhadap mortalitas pasien EDH yang menjalani operasi kraniotomi emergensi yaitu usia $(p=0,012)$, Jenis kelamin $(p=0,418)$, GCS inisial $(p=0,146)$, abnormalitas pupil $(p=0,973)$, lama onset ( $p$ $=0,883)$ dan lama waktu tunggu $(p=0,146)$. Angka kematian 7 dari 26 pasien. Usia pasien yang menjalani kraniotomi emergensi berpengaruh secara signifikan terhadap mortalitas, sedangkan jenis kelamin, gcs inisial, abnormalitas pupil, lama onset trauma dan lama waktu tunggu berpengaruh tidak signifikan terhadap mortalitas.
\end{abstract}

Kata kunci: epidural hematoma, mortalitas.

Affiliasi penulis : 1. Pendidikan Dokter Spesialis Bedah FK Unand (Fakultas Kedokteran Universitas Andalas), 2. Bagian Bedah Divisi Bedah Syaraf RSUP Dr. M. Djamil, Padang.

Korespondensi :amrizal230312@gmail.com Telp: 085263019902

\section{INTRODUCTION}

Traumatic brain injury is a worldwide health problem frequently causing death within the ages of the second and fourth decades. Epidural hematoma $(\mathrm{EDH})$ is the accumulation of blood between the bones of the skull and the dura mater, contributing to the incidence of $1-5 \%$ of all brain injuries. EDH is an emergency case in neurosurgery with a mortality of $2.7 \%$ to $10.1 \% .^{1,2,3}$ Several factors influencing the predictive value of post-craniotomy mortality are pupillary dilatation and Glasgow Coma Scale (GCS) at arrival, age, velocity of bleeding volume addition, dimension and location of hematoma, and time interval from pupillary changes to surgery. ${ }^{4}$

Brain tissue injury secondary to EDH proceeds from ischemia or hypoxia. Lowered adenosine triphosphate (ATP) results in membrane pump failure, cytotoxic edema and cell death. The effects of hypoxia or ischemia, especially on severe head injuries, are elevated intracranial pressure (ICP) followed by the sloping down of cerebral perfusion pressure (CPP). Increased ICP generates ischemia and cerebral herniation, leading to mortality and disability of brain injury patients. ${ }^{5}$

Based on the medical records of Dr. M. Djamil General Hospital, Padang, Indonesia in 2017, within $26 \mathrm{EDH}$ cases that were evacuated by emergency craniotomy, the mortality rate reached $26 \%$. Among the factors predisposing mortality other than age, were GCS upon emergency department arrival and time interval before an evacuation craniotomy was performed.

\section{METHODS}

This study used descriptive analytic, and was conducted in Dr. M. Djamil General Hospital, Padang, Indonesia, from January to December 2017. The study population consisted traumatic brain injury patients with $\mathrm{EDH}$ who underwent emergency craniotomy at the Dr. Dr. M. Djamil General Hospital. Samples were taken by total sampling and $26 \mathrm{EDH}$ patients who underwent emergency craniotomy were obtained

Subsequent to performed emergency craniotomy, Glasgow Outcome Scale (GOS) was recorded when the patients were about to leave the hospital. GOS with a score of 1 (death) was inability to survive or death without consciousness recovery, score of 2 (persistent vegetative) was severe damage with prolonged state of unresponsiveness and a lack 
of higher mental functions, score of 3 (severe disability) was severe injury with permanent assistance for daily living activities, score of 4 (moderate disability) was possible employment with special equipment, no need for assistance in everyday life, score of 5 (mild disability or good recovery) was light damage with minor neurological and psychological deficits, and possible employment engaging daily activities. Statistical analysis was performed using SPSS 23.0 with bivariate analysis of Chi-square test $(p<0.05)$

\section{RESULTS}

The mean of age of EDH patients was $24,46 \pm 15.76$. The mean of waiting duration for the treatment group was $6,23+2,79$ hours with trauma onset of $13,46 \pm 17,06$ hours. The characteristics of inisial GCS, gender, pupil abnormality, waiting duration, and trauma onset did not differ significantly between treatment and control groups (Table 1).

Table 1. Baseline characteristics

\begin{tabular}{|c|c|c|c|}
\hline Characteristics & $\begin{array}{c}\text { Survivor } \\
n=19 \\
(73,07 \%)\end{array}$ & $\begin{array}{c}\text { Death } \\
n=7 \\
(26,92 \%) \\
\end{array}$ & $\begin{array}{c}\mathbf{P} \\
\text { value }\end{array}$ \\
\hline \multicolumn{4}{|l|}{ Gender } \\
\hline Male & $14(73,68 \%)$ & $4(57,14 \%)$ & 0.418 \\
\hline Female & $5(26,31 \%)$ & $3(42,86 \%)$ & \\
\hline \multicolumn{4}{|l|}{ Age } \\
\hline$<40$ years & $17(89,47 \%)$ & $3(42,86 \%)$ & $0.012^{*}$ \\
\hline $\begin{array}{l}>40 \\
\text { years }\end{array}$ & $2(10,53 \%)$ & $4(57,14 \%)$ & \\
\hline \multicolumn{4}{|l|}{ Pupil abnormality } \\
\hline Isochors & $11(57,89 \%)$ & $4(57,14 \%)$ & 0.973 \\
\hline Anisochor & $8(42,10 \%)$ & $3(42,86 \%)$ & \\
\hline \multicolumn{4}{|l|}{ Onset trauma } \\
\hline$<12$ hours & $13(68,42 \%)$ & $5(71,43 \%)$ & 0.883 \\
\hline $\begin{array}{l}>12 \\
\text { hours }\end{array}$ & $6(31,58 \%)$ & $2(28,57 \%)$ & \\
\hline \multicolumn{4}{|l|}{ Delayed time } \\
\hline$<4$ hours & $3(15,79 \%)$ & $3(42,86 \%)$ & 0.146 \\
\hline$>4$ hours & $16(84,21 \%)$ & $4(57,14 \%)$ & \\
\hline \multicolumn{4}{|l|}{ GCS } \\
\hline$<8$ & $7(36,84 \%)$ & $5(71,43 \%)$ & 0.117 \\
\hline$>8$ & $12(63,16 \%)$ & $2(28.57 \%)$ & \\
\hline \multicolumn{4}{|c|}{$\begin{array}{l}\text { Statistical Significance Based On chi-square test }(p< \\
0,05)\end{array}$} \\
\hline DISCUSSION & & & \\
\hline
\end{tabular}

Study by Jeong et al. denoted the mean of age for $\mathrm{EDH}$ cases was $39.73 \pm 21.48$ years. ${ }^{8}$ In this study, it was found that the mean of age of EDH patients was $25 \pm 12.75$ years in the treatment group and $21.73 \pm 14.83$ years in the control group. Taussky et al. pointed that craniotomy procedure in younger age groups delivered more favorable outcome. It was showed that patients with age of $<20$ years hold higher favorable outcome $(89 \%)$ than the older age group, $>60$ years $(29 \%) .{ }^{9}$ Study conducted by Niryana et al. also exhibited that the age group of $<40$ years yielded favorable outcome of $56.7 \%$, higher than the age group of $>40$ years at $15 \% .{ }^{10}$

Study by Taussky et al. divided the initial GCS group with the cut-off point of 8 . It was found that the favorable outcome of the initial GCS $>8$ was $70 \% .^{9}$
The study conducted by Niryana et al. showed favorable outcome of $63.3 \%$ if initial GCS $>8$, and $8.3 \%$ if initial GCS $<8 .{ }^{10}$ Study by Jeong et al. exhibited favorable outcome in mild brain injury at $71.26 \%$, followed by moderate brain injury at $22.27 \%$, and severe brain injury at $6.48 \%{ }^{8}$

The mean duration of waiting time in this study for the treatment group was $7.53 \pm 4.14$ hours with trauma onset of $17.67 \pm 14.53$ hours, while the control group was $6.07 \pm 1.44$ hours, with trauma onset of $20.4 \pm 18.47$ hours. According to study conducted by Jeong et al. favorable outcome was at $79.18 \%$ if the duration of waiting time was $<6$ hours and $20.82 \%$ for $>6$ hours. $^{8}$ In the study of Taussky et al. there was no significant difference on the outcome of EDH patients who underwent emergency craniotomy with time interval of $<3$ hours and $>3$ hours. ${ }^{9}$ Study by Niryana et al. stated that the duration of waiting time $<12$ hours yielded higher favorable outcome by $61.7 \%$, compared to $>12$ hours by $10 \% .{ }^{10}$

$\mathrm{EDH}$ is a complex entity of trauma in which the neurologic damage evolved after the impact. Different mechanisms of injury with EDH are usually involve creating a diverse traumatic environment. In addition, different types of brain injury result in multiple subdivisions of inconstant consequences. ${ }^{8}$

As the population ages with longer life expectancy, trends of injury have also been changing with more injuries in geriatric population. As well as we have already witnessed in the analysis of our database, age is the major determinant of functional outcome. It is imperative to be aware of the new injury types in geriatric population. ${ }^{10}$

As far as degree of brain injury is concerned, one will immedietly think of the pathological mechanism of early even of TBI, which is still much less understood though there is a great effort of basic research at the cellular level. Degree of brain injury is often characterized by severed brain swelling. EDH with additional intracranial injury would act together in a simultaneous manner implicating to worsen the patient condition. The accumulative damage will add on to escalate the extend of brain injury which will eventually affect the functional outcome. But in our analysis, we did not find significant relationship both degree of consciousness and outcome. GCS measurement is fluctuating from time to time and it may be change dramatically early after injury. The proper assessment of initial GCS should be carried out ideally after hemodynamic and respiratory resuscitation of TBI patient. ${ }^{6}$

Clinical deterioration of patient with EDH and its time dependent enlargement. Onset trauma more than 6 hours had an increased risk of hematoma enlargement. Ct scan serial in non-operative EDH patient should be obtained within 6-8 hours after initial injury for better outcome with prompt decision of treatment. According to the guideline of brain trauma foundation, the volume of EDH and initial GCS are determinant of surgical indication of EDH. Surgery 
within 24 hours is indicative of a fast progressive of disease, whereas the surgery 24 hours after trauma somewhat suggest a slow nature in development of hematoma enlargement. $^{7}$

\section{CONCLUSION}

The primary aim of present study was to investigate how clinical parameters influence the patient outcome. prehospital care, diagnostic instrument, critical care monitoring, and treatment have to be changed and validated continuously for better outcome. Age, degree of brain injury and GCS, pupil abnormality, onset trauma, delayed time for surgery are determinant factor to outcome however in this analysis only age has significant factor to outcome.

\section{REFERENCES}

1. Ndoumbe A, Ekeme MVP, Jemea B, Simeu C, Takongmo S. Epidemiological Analysis of Surgically Treated Acute Traumatic Epidural Hematoma. OJMN. 2016; 6:3-8. http://dx.doi.org/10.4236/ojmn.2016.63016

2. Gupta S, Iv V, Sam N, Vuthy D, Klaric K, Shrime MG, Park KB. Impact of Helmet Use on Severity of Epidural Hematomas in Cambodia. World Neurosurg. 2017; 100:267-270. http://dx.doi.org/10.1016/j.wneu.2016.12.104

3. Bir SC, Maiti TK, Ambekar S, Nanda A. Incidence, hospital costs and in-hospital mortality rates of epidural hematoma in the United States. Clin Neurol Neurosurg. 2015; 138:99-103. http://dx.doi.org/10.1016/j.clineuro.2015.07.02

4. Cheung PSY, Lam JMY, Yeung JHH, Graham $\mathrm{CA}$, Rainer TH. Outcome of traumatic extradural haematoma in Hong Kong. Injury, Int. J. Care Injured. 2007; 38:76-80. http://dx.doi.org/10.1016/j.injury.2006.08.059

5. Mendelow AD, Crawford PJ. Primary and Secondary Brain Injury. In: Reilly $P$, Bullock R, editors. Head Injury. London: Chapman \& Hall; 1997; 30:56-79.

6. Wakai A, McCabe A, Roberts I, Schierhout G. Mannitol for acute traumatic brain injury. Cochrane Database Syst Rev. 2013; 8:84-92. http://dx.doi.org/10.1002/14651858.CD001049.pu b5

7. Wani AA, Ramzan AU, Nizami F, Malik NK, Kirmani AR, Bhatt AR, Singh S. Controversy in use of mannitol in head injury. Indian Journal of Neurotrauma (IJNT). 2008; 5(1):11-13. http://dx.doi.org/10.1016/S0973-0508(08)80022-6

8. Jeong $\mathrm{YH}, \mathrm{Oh} \mathrm{JW}$, Cho S. Clinical Outcome of Acute Epidural Hematoma in Korea: Preliminary Report of 285 Cases Registered in the Korean Trauma Data Bank System. Korean J Neurotrauma. 2016;12(2):47-54.

http://dx.doi.org/10.13004/kjnt.2016.12.2.47

9. Taussky P, Widmer HR, Takala J, Fandino J. Outcome after acute traumatic subdural and epidural haematoma in Switzerland: a singlecentre experience. Swiss Med Wkly. 2008;138(19-20):281-28. http://dx.doi.org/2008/19/smw-12056

10. Niryana W, Teddy H, Golden N, Widyadharma E. Related Risk Factors and Outcome of Patients Post Trepanation Epidural Hematoma
Evacuation. Biomed Pharmacol J. 2017; 10:2539. http://dx.doi.org/10.13005/bpj/1161

11. Myburgh JA, Lewis SB. Mannitol for Resuscitation in Acute Head Injury: Effects on Cerebral Perfusion and Osmolality. Crit Care Resusc. 2000; 2:14-18. PMID: 16597278. 